\title{
大腿骨頝部内側骨折に対する骨接合術による治療経験
}

\author{
熊本整形外科病院 \\ 生田拓也・古 代 裕次郎 \\ 荘 念仁・中 村 真 \\ 藤 原明

\section{Osteosynthesis for Intracapsular Fracture of the Femoral Neck} \\ by \\ Takuya Ikuta, Yujiro Furushiro, Yomihito Soh, \\ Makoto Nakamura and Akira Fujiwara \\ Kumamoto Orthopaedic Hospital
}

Thirty-eight fractures of the intracapsular femoral neck were treated with internal fixation. They were classified into stage 1 (6cases), stage II (24cases), stage III (2cases), and stage IV (6cases) according to Garden's staging classfication.

All cases except one achieved bony union. There was only one case of non-union, and two cases with late segmental collapse. The rate of non-union and late segmental collapse was $8 \%$, which was relatively low.

We conclude that osteosynthesis, when adequately indicated for intracapsular fractures of the femoral neck, achieves good results.

Key words : femoral neck (大腿骨䅡部), Intracapsular fracture（内側骨折), Osteosynthesis（骨接合 術)

\section{は じめに}

大腿骨頝部内側骨折は骨接合術を行った場合，偽関 節や骨頭壞死の可能性が少なくなく，その治療に考慮 を要す. 我々は本骨折の若青壮年者における場合は Garden stage に関係なく骨接合術, また高齢者の場 合は原則的に Garden stage I 及びII に対して骨接合 術, stage III 及び IV に対しては人工骨頭置換術を選 択している.

今回はその骨接合術について治療成績を検討し報告 する。

$$
\text { 対 象 }
$$

1988 年 4 月より 1993 年 12 月までに当院にて観血
的治療を行った大腿骨䅡部内側骨折 201 例中，骨接合 術を行った症例は 41 例で，このうち follow up 可能 であった 38 例を対象とした。男性 13 例, 女性 25 例, 年齢は 18 91 歳, 平均 65.8 歳であった. 受傷原因は 転倒 29 例, 交通事故 5 例, 転落 3 例, その他 1 例で 高齢者は全例，転倒が原因であった（表 1 ）。

骨折型は Garden stage 分類をを用い，その内訳は stage I : 6 例, II : 24 例 (stage I, II 平均年齢 72.1 歳), III : 2 例, IV $: 6$ 例 (stage III, IV平均年 令 41.9 歳) であった.

術後観察期間は術後 6 力月～ 6 年 1 力月, 平均 2 年 7 カ月であった (表 2 ). 
表 1 症例の概要

症例 38 例 (1988.4 1993.12)

性別 男: 13 例 女: 25 例

年齢 $18 \sim 91$ 歳, 平均 65.8 歳

受傷原因

転倒：29例

交通事故：5例

転落：3 例

その他：1例

術後観察期間

6 力月～ 6 年 1 力月, 平均 2 年 7 力月

表 2 骨折型と固定方法

\begin{tabular}{|c|c|c|c|c|c|c|}
\hline $\begin{array}{c}\text { 固定法 } \\
\text { Garden } \\
\text { 分類 }\end{array}$ & $\begin{array}{r}\text { Knowles } \\
\text { pin }\end{array}$ & CCHS & screw & CHS & 訫 & 年齢 (平均) \\
\hline Stage I & 1 & 2 & & 3 & 6 & \\
\hline II & 4 & 2 & 1 & 17 & 24 & 了 12.1 叔 \\
\hline III & & & & 2 & 2 & \\
\hline IV & & 1 & 1 & 4 & 6 & 政 \\
\hline 計 & 5 & 5 & 2 & 26 & 38 & \\
\hline
\end{tabular}

治 療

用いた内固定材料はノールズピン 5 例, Cannulated Cancellous Hip Screw (以下 CCHS と 略） 5 例，髄内釘に伴う Screw 2 例（以上 Multiple screw 群, 以下 MS 群と略), Compression Hip Screw（以下CHSと略）26 例であった（表 2)。ノー ルズピンは初期に用いたもので, 現在は基本的に CHS（できればチタン製）を用い，若年者には CCHSを用いている.

後療法は, 手術翌日より免荷起立訓練を開始し, 部 分荷重は MS 群平均 5.3 週, CHS 3.4 週で開始した。

\section{結果}

偽関節を stage II の 1 例（術後早期の screw の cut out）に認め, Late segmental collapse（以下 LSC と略）を stage IIの 1 例（術後 11 力月), stage IVの 1 例（術後 7 力月）の計 2 例に認めた。これら 3 例に 対し人工骨頭置換術を施行した。残り 35 例は順調に
骨瘾合が得られ，LSC を認めていない。

$$
\text { 症例 }
$$

症例 1.48 歳, 女性, Garden stage III.

交通事故にて受傷. 17 日後, CHS にて骨接合術施 行. 術後 3 週にて部分荷重開始し, 術後 4 週にて全荷 重とした。術後 1 年で抜釬術を行ない, 術後 2 年の現 在, 疼痛なくX線像にても特に異常を認めない (図 1 ). 症例 2.59 歳, 女性, Garden stage IV.

転倒して受傷。4 日後, CHS にて骨接合術施行. 術後 3 週にて部分荷重開始し, 術後 8 週で全荷重とし た。術後 7 力月にて collapse を起こし，人工骨頭置 換術を施行した（図 2).

\section{考察}

本骨折の特徴は高齢者に多く，骨接合術を行なった 場合, 偽関節や LSC が発生する可能性があり, Garden stage III，IVではその発生率が有意に高率と なることである。

我々は高齢者の骨折治療の原則は早期離床, リハビ リテーションであると考えている．高齢者の本骨折の 場合, 前記の特徴を考慮し, stage III, IVの場合, 術 後リハビリテーションが早く成績が安定している人工 骨頭置換術を行なっている。また stage I， IIの場合 には骨接合術を選択しているが，この場合も長期間の 免荷は不都合かつ不必要と考え, 固定法として CHS を用い大腿骨頝部外側骨折の場合と同様に術後 $2 \sim 3$ 週より荷重を開始している.

一方，若青壮年者の本骨折の場合は骨頭温存を第一 とすべきと考え，Garden stage に関係なく骨接合術 を行なっている．特に若年者の場合は術後リハビリテー ションが長期になっても, 確実な方法を選択すべきで, 固定方法も骨頭血流を少しでも温存する目的にて CCHS を主に用いている。

以上の様な適応にて当院の本骨折に対し観血的治療 を行なった症例中, 人工骨頭置換術を行なった群の平 均年齢は 79.0 才であったのに対し，骨接合術を行なっ た群の平均年齢は 65.8 才であった。

また，我々の骨接合術における偽関節及び LSC の 発生率は $8 \%$ (stage I, II : $6 \%=2 / 30$, stage III, IV : $12.5 \%=1 / 8$ ）であった。諸家の報告では 10〜30 \%の発生率が多(2) 5), 9). 我々は高齢者の stage III, IVに対して骨接合術を施行しておらず，また，術後観 


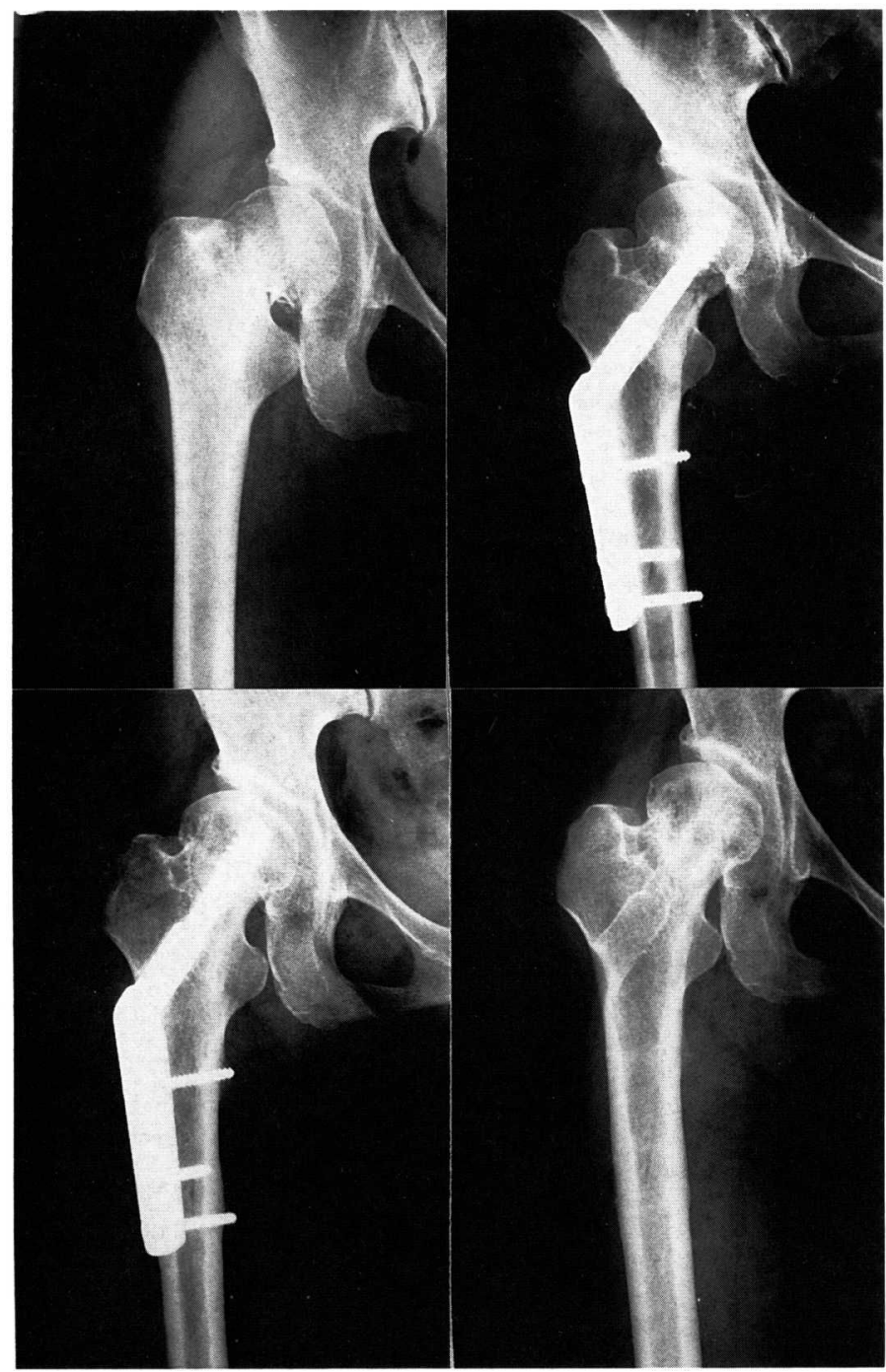

図 1 症例 1 , 48 歳, 女性, Garden stage III

\begin{tabular}{|l|l|}
\hline $\mathrm{a}$ & $\mathrm{b}$ \\
\hline $\mathrm{c}$ & $\mathrm{d}$ \\
\hline
\end{tabular}
a. 術前
b. 術後
c. 術後 1 年
d. 術後 2 年

察期間も比較的短期であるので諸家との単純な比較は できないものの, 低い発生率であった.

以上より，本骨折に対する骨接合術は適応を厳密に すれば良好な結果を得られることが伴ったが, 適応と なる年齢を何歳にするか（高齢者を何歳からとするか） という問題が残る. 我々は人工骨頭の寿命を $10 〜 15$
年と考え, 一応 65 歳にて線をひいているが今後は今 回の良好な結果をふまえ，いわゆる高齢者の stage III, IVであっても, 充分な理解力, 運動能力を有していれ ば，インフォームドコンセントにより骨接合術を選択 してもよいのかもしれない. 


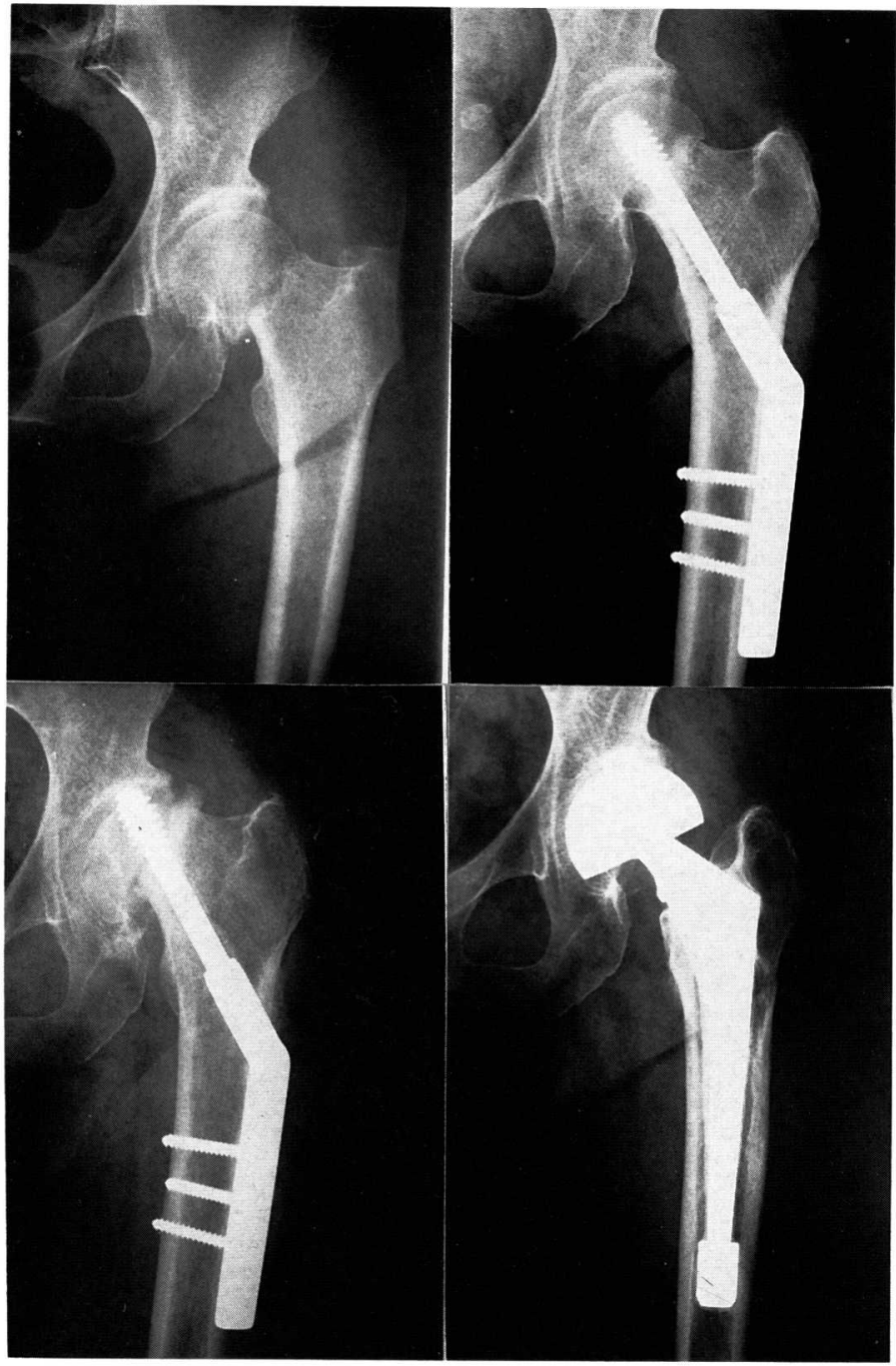

図2 症例 2, 59 歳, 女性, Garden stage IV

\begin{tabular}{|l|l|l|l|l}
\hline $\mathrm{a}$ & $\mathrm{b}$ & $\begin{array}{l}\text { a. 術前 } \\
\text { b. 術後 }\end{array}$ \\
\cline { 1 - 1 } $\mathrm{c}$ & $\mathrm{d}$ & $\begin{array}{l}\text { c. 術後 } 7 \text { 力月 } \\
\text { d. 人工骨頭置換術後 }\end{array}$ \\
\hline
\end{tabular}

\section{ま と め}

1. 当院にて骨接合術を行なった大腿骨頝部内側骨 折 38 例について検討した。

2 . 偽関節, LSC の発生率は $8 \%$ で低い発生率で あった。
3. 本骨折に対する骨接合術は適応を厳密にすれば 良好な結果が得られることが伴った。

\section{参 考 文 献}

1) Garden, R. S. : Low-angle fixation in farctures of the femoral neck. J. Bone Joint Surg., 43-B : 647-663, 
1961.

2）可徳三博ほか：大腿骨頝部骨折に対する骨接合術不良 例の検討. 整形外科, $43: 1873-1878,1992$.

3) 中嶋 裕ほか: 若青壮年者の大腿骨頝部内側骨骨折. 整形外科, $37: 1033-1040,1986$.

4）西 壽二ほ加：大腿骨䅡部内側骨折内固定の検討. 整 形外科と災害外科, $41: 223-227,1992$.

5）白濱正博ほか：大腿骨䅡部内側骨折の骨接合術症例の 検討一とくに Cannulated Cancellous Screw 固定法に
ついて一. 骨折, $13: 234-238,1991$.

6）山本 真ほか：高齢者大腿骨頝部骨折の病態と治療. 日整会誌，65：408-424，1991.

7）山本真：大腿骨頝部内側骨折の転位と破砕 - 骨欠損に ついて. 整形外科, 30:257-265, 1979.

8）山室隆生ほか：外傷性大腿骨頭壊死. 整形外科 Mook, $24: 221-238,1982$.

9）吉本隆昌ほか：大胜骨頝部内側骨折に対する骨接合術 の検討. 骨折, $14: 94-98$, 1992. 